\title{
Reconhecimento e celebridade: Jean-Jacques Rousseau e a política do nome próprio*
}

Antoine Lilti*

\section{RESUMO}

Diferentemente de inúmeros autores das Luzes, que utilizavam pseudônimos ou recorriam ao anonimato, Jean-Jacques Rousseau sempre publicou sob seu nome próprio e reivindicou em alto grau seu nome de autor. Essa verdadeira política do nome próprio era tanto coerente como assumida, ditada por uma concepção de responsabilidade do escritor, mas também por uma demanda de reconhecimento social e pessoal. Ora, a partir dos anos 1760, Rousseau descobre as armadilhas da celebridade: o desejo de reconhecimento transforma-se em inquietação diante da curiosidade insaciável do público.

Palavras-chave: regimes de celebridade; nome de autor; estatuto social do escritor.

\section{ABSTRACT}

Unlike numerous Enlightenment authors, who used pennames or wrote anonymously, Jean-Jacques Rousseau always published under his own name, and held in high esteem his name as an author. It constituted a coherent and admitted policy, dictated by the writer's sense of responsibility but also by a request for social and personal recognition. Alas, from the 1760 s, Rousseau found out the traps of celebrity: the desire for recognition becomes uneasiness when confronted to the public's insatiable curiosity.

Keywords: celebrity regimes; author's name; author's social statute.

Tradução - DOI - http://dx.doi.org/10.1590/2237-101X015029010

* Artigo originalmente publicado como: Reconnaissance et célébrité: Jean-Jacques Rousseau e la politique du nom propre. Orages. Littérature et Culture 1760-1830, Paris, n. 9, p. 77-93, mar. 2010. Tradução de Raquel Campos, doutora em história social pela Universidade Federal do Rio de Janeiro.

** Diretor de estudos na École des Hautes Études en Sciences Sociales (EHESS). Paris, França, E-mail: antoine.lilti@ehess.fr. 
Se há um autor que encarna, no final do século XVIII, aquilo que se costumou chamar, com Paul Bénichou, de "a consagração do escritor", ele é certamente Jean-Jacques Rousseau. Autor célebre ainda em vida, profeta republicano da democracia por vir, panteonizado durante a Revolução, ele acumula em seu nome os diferentes aspectos dessa consagração: celebridade do escritor, afirmação de um poder espiritual laico, culto do grande homem. ${ }^{1}$ Entretanto, a questáo complica-se, se levarmos em conta o fato de o próprio Rousseau ter vivido de maneira extremamente ambivalente, mesmo dolorosa, essa consagração em vida. Todos os textos de seus últimos anos testemunham uma profunda dificuldade em assumir o olhar lançado sobre ele pelo público para o qual escreveu. Aquilo a que se chamou às vezes de "a paranoia" de Rousseau é, em primeiro lugar, a expressão existencial, mas manifestada literariamente, de uma reação extrema ao novo regime de celebridade que está se estabelecendo e do qual ele é a figura mais marcante. ${ }^{2}$

No cerne desse regime de celebridade, o nome próprio desempenha um papel essencial: ele é tanto um nome de autor, a autoridade à qual se deve remeter a obra publicada, quanto uma identidade social e o nome de um personagem cujos feitos e gestos são narrados pelas gazetas europeias e sobre o qual circulam boatos. ${ }^{3} \mathrm{O}$ nome é um vetor essencial do reconhecimento social, mas é também um dos elementos da identidade pessoal. Ora, justamente, Rousseau não deixou de ser obnubilado pelos usos possíveis do seu nome, de uma maneira bastante impressionante, e todavia pouco assinalada pelos comentadores. Mesmo não sendo o mais lido dos escritos de Rousseau, Rousseau juiz de Jean-Jacques. Diálogos é, desse ponto de vista, um texto apaixonante - e poderá nos servir de ponto de partida. Ele é composto por três diálogos entre um personagem denominado Rousseau e um outro designado simplesmente como "O Francês" - diálogos que dizem respeito a um terceiro personagem, "Jean-Jacques", autor de $O$ contrato social, de Emílio e de $A$ Nova Heloísa, e sobre o qual se trata de demonstrar se ele é realmente o homem mau descrito pelo Francês e se o complô universal tramado contra ele — cuja existência não é jamais colocada em dúvida — justifica-se.

Como o indica essa descrição muito simples, a particularidade desse texto singular consiste em cindir a referência de Rousseau a si próprio, entre seu nome "Rousseau", que ele converte na designação de outro que não si mesmo, encarregado de fazer-lhe justiça; e "Jean-Jacques", um prenome - que corresponde, de um lado, ao que ele tem de mais íntimo, à

\footnotetext{
${ }^{1}$ BÉNICHOU, Paul. Le sacre de l'écrivain : Essai sur la naissance d'un pouvoir laïque dans la France moderne. Paris: Gallimard, 1973; BONNET, Jean-Claude. Naissance du Panthéon : Essai sur le culte des grands hommes. Paris: Fayard, 1998; BACZKO, Bronislaw. Job, mon ami: Promesse du bonheur et fatalité du mal. Paris: Gallimard, 1997; DIAZ, José-Luis. L'Écrivain imaginaire: Scénographies auctoriales á l'époque romantique. Paris: Champion, 2007.

${ }^{2}$ LILTI, Antoine. The Writing of Paranoïa: Jean-Jacques Rousseau and the Paradoxes of Celebrity. Representations, n. 103, p. 5-80, Summer 2008.

${ }^{3}$ BIRN, Raymond. Fashioning and Icon: Jean-Jacques Rousseau and the Mémoires secrets. In: FORT, Bernadette; POPKIN, Jeremy (Ed.). The Mémoires secrets and the Culture of Publicity in Eighteenth-Century France. Oxford: The Voltaire Foundation, 1998.
} 
sua individualidade própria, àquilo que o distingue dos outros Rousseau, e que, de outro, tornou-se a designação particular de um personagem público. Como compreender essa cisão, uma vez que se recuse acrescentar uma suspeita de esquizofrenia à já extensa ficha médica de Rousseau? Uma interpretação possível vê aí uma reflexão sobre o processo de individualização. A produção de uma relação autêntica consigo mesmo passaria primeiramente pela narrativa do eu (As Confissóes e o projeto autobiográfico de se contar), e depois pelo questionamento da referencialidade do nome próprio. Com Rousseau descobrir-se-ia, então, o problema da ancoragem da enunciação: a distância entre o "eu" sujeito da fala e o "mim" objeto da fala. Ora, a identidade em crise não pode ser restaurada e reconfortada em sua unidade senão por uma reflexão sobre a ancoragem da enunciação daquele que julga. Análise sedutora, simultaneamente linguística e filosófica, que destaca o fato de que, em um contexto de fluidificação das identidades sociais, a questão do nome próprio como fixação de uma individualidade torna-se um problema essencial. ${ }^{4}$

Meu ponto de vista, neste artigo, será diferente. Trata-se de privilegiar uma leitura que insista sobre o nome próprio náo como o garantidor de uma identidade do eu, mas como o garantidor do texto, isto é, que insista sobre o lugar do nome nas estratégias autorais de Rousseau e nos procedimentos do reconhecimento literário. A questão historiográfica é, portanto, menos a do indivíduo democrático que a do autor moderno confrontado à responsabilidade por seus textos e ao olhar do público. Desse ponto de vista, torna-se preciso considerar uma das fórmulas fortes do preâmbulo dos Diálogos: "Tomei a liberdade de retomar nessas entrevistas o meu sobrenome, do qual o público julgou apropriado privar-me - e, seguindo seu exemplo, designei-me como a um terceiro, utilizando o nome de batismo ao qual lhe aprouve reduzir-me". ${ }^{5}$ Contra sua redução, pelo público, a um personagem "J.-J.", objeto de julgamentos contraditórios, Rousseau intenta reapropriar-se de seu sobrenome, que é tanto uma identidade social (remete, portanto, a uma família; é o nome do pai) quanto o nome de autor por ele sempre reivindicado, como veremos. É preciso atentar para o caráter paradoxal dessa afirmação, visto que Jean-Jacques é a designação favorita não dos inimigos de Rousseau, mas de seus amigos e admiradores. O que está em jogo, aqui, é a inversão do público e do privado, fenômeno característico dos mecanismos da celebridade. Nesse sentido, é impressionante que inúmeros biógrafos de Rousseau utilizem, por seu turno, o prenome Jean-Jacques para marcar uma relação de empatia com seu objeto — relação teorizada como infinitamente problemática por Rousseau.

Do ponto de vista de uma história do reconhecimento literário, a própria posição de Rousseau é profundamente ambivalente. É tanto intelectual quanto afetiva a necessidade de

\footnotetext{
${ }^{4}$ GARETTA, Anne. Rousseau, juge de Jean-Jacques: Individu, identité et référence du nom propre. In: BROUARD-ARENDS, Isabelle (Dir.). Lectures de Rousseau : Les Dialogues. Rennes: Presses Universitaires de Rennes, 2003.

${ }^{5}$ ROUSSEAU, Jean-Jacques. Rousseau juge de Jean-Jacques. Dialogues. Oeuvres complètes. t. I. Paris: Gallimard, 1959. p. 663.
} 
reconhecimento que o anima. Toda a sua teoria da leitura como acesso empático à intenção moral do autor esforça-se precisamente para combater o fosso entre os mecanismos do sucesso literário e um autêntico reconhecimento interpessoal. Vão empreendimento, pois o risco intrínseco ao próprio sucesso é que o conhecimento do autor, ou antes das narrativas públicas atribuídas ao seu nome próprio, seja acompanhado por um desconhecimento da obra - interditando, por conseguinte, o reconhecimento do homem. Ora, se termina por se considerar como emboscado pela celebridade de seu nome, Rousseau é sem dúvida o escritor do século XVIII que mais divulgou seu patronímico, até o ponto de fazer dele um dos elementos essenciais de sua postura autoral e de sua relação com o discurso filosófico. Essa política do nome próprio diz respeito essencialmente a dois aspectos: a responsabilidade penal e a relaçáo com a censura, de uma parte; e, de outra, o nome como vetor da notoriedade individual — isto é, o renome, precisamente. ${ }^{6}$ De um lado, o nome torna-se o garantidor de uma autoria que é, simultaneamente, autoridade e responsabilidade; de outro, os mecanismos da celebridade literária instauram um verdadeiro mercado dos nomes, garantindo uma espécie de "monopólio da reputaçáo". 7 Ficam por compreender as questóes e as ambiguidades dessa política do nome próprio: veremos, portanto, por que razóes Rousseau não parou de publicar seu nome, contra todos os códigos contemporâneos da prudência filosófica e da modéstia literária, antes de ser perseguido pela angústia de que seu nome, sob o efeito da celebridade, acabasse por se voltar contra si, interpondo-se entre ele e sua obra, entre ele e seus leitores.

\section{A política do nome próprio}

Um dos elementos mais evidentes da política rousseauniana do nome próprio é a recusa sistemática de publicar sob pseudônimo ou anonimamente. No século XVIII, o anonimato permanecia, contudo, uma prática corrente, perfeitamente aceita e justificada, em particular quando se tratava de obras heterodoxas ou simplesmente audaciosas. De Pierre Bayle a Voltaire, os filósofos das Luzes tornaram uma especialidade sua a inventividade em matéria de pseudônimos e de estratégias alambicadas de publicaçôes arrevesadas. Em Bayle, trata-se seguramente de uma estratégia de prudência, mas ela corresponde também à sua própria concepçáo do discurso filosófico, em que o autor apaga-se diante de uma diversidade de referências e de autoridades no interior de um texto cuja polifonia oferece a garantia de escapar a qualquer dogmatismo. ${ }^{8}$ Meio século mais tarde, o Barão de Holbach, o mais sistemático

\footnotetext{
${ }^{6}$ Seria necessário acrescentar, evidentemente, a questão da relação de Rousseau com a propriedade intelectual de suas obras e com o direito de autor. Sobre essa questão, de que náo tratarei no quadro deste artigo, ver TURNOWSKI, Geoffrey. The Enlightenment Literary Market: Rousseau, Authorship and the Book Trade. Eighteenth Century Studies, v. 3, n. 36, p. 387-410, 2003.

${ }^{7}$ LECLERC, Gérard. Le Sceau de l'oeuvre. Paris: Éditions du Seuil, 1998. p. 101.

${ }^{8}$ MORI, Gianluca. Anonymat et stratégies de communication : le cas de Pierre Bayle. La Lettre Clandestine, n. 8, p. 19-34, 1999.
} 
teórico do ateísmo e do materialismo, atribui todas as suas obras a autores mortos, como Mirabaud e Boulanger, alcançando êxito em dissimular rigorosamente, e até à morte, sua autoria. Isso lhe permite, à diferença de autores libertinos do século precedente, renunciar inteiramente às práticas de escrita equívoca, mas ao preço — perfeitamente assumido e reivindicado por Holbach — de uma renúncia completa à sua glória pessoal, à celebridade de autor. ${ }^{9}$ Em Voltaire, há uma dimensão lúdica mais afirmada, já que se trata de jogar com toda uma gama de possibilidades, indo da verdadeira dissimulação do autor até à negação de conveniência que não permite, na verdade, qualquer dúvida. Voltaire, como é bem sabido, é um caso típico da diferença entre o pseudônimo como máscara, que visa a dissimular o autor, e o pseudônimo como marca, que visa, pelo contrário, a afirmar a liberdade fundamental do escritor, ao criar uma identidade própria de autor. Voltaire é um pseudônimo, mas cujo objetivo não é de modo algum mascarar o autor; pelo contrário, este é precisamente seu nome de autor, oposto a uma identidade social (Arouet) da qual ele teve justamente de se desfazer para abraçar a carreira literária. Esse uso do pseudônimo como nome de pena participa do regime de singularidade do escritor, ${ }^{10}$ nós o reencontraremos sobretudo no século XIX, com Stendhal e outros. Mas Voltaire passa seu tempo também dissimulando seu pseudônimo reconhecido por trás de uma profusão (mais de 160) pseudônimos-máscaras que servem de véu, em uma espécie de comédia inesgotável povoada de autores fictícios, que lhe permitem intervir em todas as frentes, preservando ao mesmo tempo toda a sua liberdade. Em Voltaire, o confronto do discurso filosófico com seus adversários é tanto real quanto paródico: ${ }^{11}$ corre-se o risco de minar a autoridade da palavra; e é contra essa estratégia que Rousseau reage muito fortemente.

Com efeito, Rousseau não parou, por seu turno, de divulgar seu nome e de assinar, de se nomear - ao menos a partir de 1751, com a publicaçáo do Discurso sobre as ciências e as artes (ou, mais exatamente, com sua segunda edição). Desde entấo, absolutamente todos os textos que ele publica são assinados com seu nome, incluindo Emílio e $O$ contrato social. $\mathrm{Na}$ Carta a D’Alembert sobre os espetáculos, a promoção do nome torna-se uma verdadeira política editorial. Rousseau opóe de modo muito explícito, desde a folha de rosto, seu próprio nome, "J.-J. Rousseau, cidadáo de Genebra", aos inúmeros títulos acadêmicos de seu interlocutor: "Ao Sr. D’Alembert, da Academia Francesa, da Academia Real de Ciências de Paris, daquela da Prússia, da Sociedade Real de Londres....". ${ }^{12}$ Doravante, o prenome, sob a forma abreviada das iniciais — essa forma mesma que ele utiliza nos Diálogos para designar Jean-Jacques —

\footnotetext{
${ }_{9}^{9}$ SANDRIER, Alain. Le style philosophique du baron d'Holbach. Paris: Champion, 2004.

${ }^{10} \mathrm{HEINICH}$, Natalie. L'Élite artiste: Excellence et singularité en régime démocratique. Paris: Gallimard, 2005.

${ }^{11}$ FERRET, Olivier. Vade mecum, vade retro. Le recours au pseudonyme dans la démarche pamphlétaire voltairienne. La Lettre Clandestine, n. 8, p. 65-82, 1999; BENREKASSA, Georges. L'interlocuteur voltairien: le masque et la plume. In: MERVAUD, Christiane; MENANT, Sylvain (Dir.). Le Siècle de Voltaire, hommage à René Pomeau. v. 1. Oxford: The Voltaire Foundation, 1987. p. 89-97.

${ }^{12}$ Ver a análise de MOSTEFAI, Ourida. Le Citoyen de Génève et la République des Lettres, étude de la controverse autour de la Lettre à D’Alembert de Jean-Jacques Rousseau. Nova York; Berlim; Oxford: Peter Lang, 2003.
} 
estará sempre presente, opondo-se ostensivamente ao título de "Senhor", conotado sempre de modo negativo. Essa vontade resoluta de se nomear, que se opóe explicitamente às práticas mais correntes dos homens de letras de sua época, é uma orgulhosa reivindicação de autoria, claramente expressa numa correspondência a Marc-Michel Rey sobre a publicação da carta a D’Alembert: "Não apenas você poderá me nomear, mas meu nome estará nela e será mesmo seu título; o profundo segredo que eu lhe peço é somente até o momento da publicação e isso, como você poderá ver pelo manuscrito, pelas mais importantes razóes para a obra e para o autor". ${ }^{13}$ Meu nome estará nela e será mesmo seu título: para além da vontade de assumir uma posição de autoria, essa fórmula orgulhosa associa a uma estratégia publicitária - fundada na consciência aguda do escândalo que o livro provocará e na notoriedade de seu autor — uma reivindicação presunçosa.

Essa promoção do nome, proclamada como um estatuto tanto social quanto político, "Jean-Jacques Rousseau, cidadáo de Genebra", é válida para todos seus escritos, quer se trate de textos filosóficos, polêmicos ou literários, incluindo aqueles que habitualmente não se assinam com o nome próprio no século XVIII, como os romances. O prefácio de A nova Heloisa é, a esse respeito, muito interessante, pois Rousseau joga com os clichês do gênero, simulando deixar aberta a questão de saber se se trata de cartas autênticas ou ficcionais, ao mesmo tempo que publica a obra com o seu nome. "Todo homem honrado deve reconhecer os livros que publica, afirma ele no prefácio. Nomeio-me, portanto, no começo desta coletânea, não para dela me apropriar, mas para por ela responder" ${ }^{14} \mathrm{~A}$ bravata é ainda mais afirmada no prefácio dialogado, publicado como apêndice da segunda edição: a seu interlocutor - que o aconselha a, prudentemente, não publicar o livro com o seu nome - Rousseau responde:

Um homem honrado ocultar-se-ia ao falar ao público? Ousa ele imprimir aquilo que não ousaria reconhecer? Eu sou o editor deste livro e nele me nomearei como editor.

N- Você se nomeará nele? Você?

R- Eu mesmo.

$\mathrm{N}-\mathrm{O}$ quêe? Você colocará nele o seu nome?

R- Sim, senhor.

$\mathrm{N}$ - Seu verdadeiro nome? Jean-Jacques Rousseau, com todas as letras?

R- Jean-Jacques Rousseau, com todas as letras. ${ }^{15}$

\footnotetext{
${ }^{13}$ ROUSSEAU, Jean-Jacques. Correspondance complète. Ralph-Alexander Leigh (Ed.). t. V. Oxford: The Voltaire Foundation, 1962-1998. p. 70-71, carta de 15 de abril de 1758.

${ }^{14}$ Id., Julie ou la Nouvelle Héloïse. Edição de René Pomeau. Paris: Garnier, 1960. p. 3. [Edição brasileira: ROUSSEAU, Jean-Jacques. Júlia ou A nova Heloísa. Campinas, SP: Editora da Unicamp; São Paulo: Hucitec, 2006.]

${ }^{15}$ Ibid., p. 753.
} 
E, com efeito, a capa da primeira edição traz o nome de Rousseau. Por trás da justificação pela sinceridade e a transparência, é preciso ver nessa discussão uma forma de exibição, um orgulho reivindicado em assinar um romance, sem dúvida mesmo uma jubilação em repetir e quase em proclamar seu nome, como também certo desafio, certa provocação, certa ostentação em romper com os códigos do decoro literário, ao afirmar o gesto autoral. Contra os preceitos da discriçấo social, Rousseau reivindica o papel do escritor e afirma a legitimidade de sua palavra. Essa postura é, aliás, coerente com sua recusa das figuras aristocráticas ou mundanas do escritor. Há nisso a afirmação da escrita não como ofício nem como passatempo, mas como vocação, até mesmo como missão, provida de uma utilidade social e pública. Essa afirmação frequentemente repetida por Rousseau - nem sempre evitando a ênfase - ${ }^{16}$ é tratada aqui de um modo bastante irônico. Mas o essencial está em que esse gesto autoral é também uma afirmação de responsabilidade: trata-se de "responder" pela obra, mas também de muni-la do peso da autoridade moral que Rousseau julga ter adquirido com suas tomadas de posição anteriores. Ora, o que está em jogo não é mais a prudência ou a modéstia literária, mas a prudência política. Isso aparece de modo muito claro quando Rousseau publica voluntariamente com seu nome o Contrato social ou o Emílio, apenas quatro anos após o escândalo provocado por Do espirito, de Helvétius, e pela condenaçáo da Enciclopédia. Trata-se ali de uma verdadeira provocação política, assim como de assumir um risco jurídico. E, com efeito, a recusa em jogar o jogo do anonimato, ainda que de fachada, irritou particularmente as autoridades e contribuiu para aumentar sua severidade. A ordem do arcebispo de Paris critica-o explicitamente, assim como a decisão do Parlamento contra o Emílio, em 9 de junho de 1762: "Que o autor desse livro, não tendo temido nomear-se, não saberia ser demasiado prontamente processado; que é importante, já que ele se fez conhecer, que a justiça coloque-se em condiçôes de fazer dele um exemplo." ${ }^{17}$

A escolha de Rousseau de assinar suas obras, de divulgar seu nome, aparece verdadeiramente como um elemento constitutivo do escândalo. As autoridades não se enganam, mas tampouco o fazem os filósofos, que assinalam justamente esse uso do nome próprio como fator escandaloso. O próprio Voltaire não compreendia por que Rousseau recusava-se a jogar o jogo da prudência e criticava-o por colocar em perigo, assim, toda a corrente filosófica. Ele anota nas margens de seu exemplar da carta a Christophe de Beaumont: "E por que você colocou seu nome nela? Pobre diabo."18 Essa condenação, tanto estratégica quanto moral, comporta também uma dimensão social, conforme o indica a fórmula "pobre diabo", que,

\footnotetext{
${ }^{16}$ Em 1762, por exemplo, Rousseau escreve a seu editor: "Que os loucos e os maus queimem meus livros o quanto quiserem, eles ainda assim náo impedirão que vivam e que sejam caros a todas as pessoas de bem. Mesmo que eles jamais voltem a ser impressos, nem por isso deixarão de alcançar a posteridade e de abençoar a memória do único Autor que nunca escreveu senão para o verdadeiro bem da sociedade e para a verdadeira felicidade dos homens." (Carta de 8 de outubro de 1762 a Marc-Michel Rey, Correspondance complète, op. cit.).

${ }^{17}$ Citado por MOSTEFAI, Ourida. Le Citoyen de Génève, op. cit., p. 115.

${ }^{18}$ Ibid., p. 114.
} 
em Voltaire, designa o escritor que pretende viver de sua pena, a "canalha literária", como por vezes ele diz, oposta à figura do escritor homem honrado.

\section{A responsabilidade do escritor}

Para Rousseau, por outro lado, a escolha de assinar seus textos era um elemento fundamental da responsabilidade política do escritor. ${ }^{19}$ Ele explicou-se a esse respeito na Carta ao Senhor de Beaumont, o arcebispo de Paris, ${ }^{20}$ e sobretudo, longamente, nas Cartas escritas da montanha, esse texto polêmico, escrito em resposta ao procurador Tronchin, no contexto agitado dos conflitos políticos genebrinos, e em seguida à condenação do Contrato social pelo Pequeno Conselho de Genebra. ${ }^{21}$ Nelas, Rousseau pede para ser julgado em pessoa, segundo o argumento de que um livro assinado náo pode ser condenado do mesmo modo que um livro anônimo; ele implica que o autor seja ouvido. A condenaçáo de um livro reconhecido por seu autor náo saberia dizer respeito unicamente ao texto, ela envolve necessariamente a intencionalidade do autor e implica, portanto, um processo completo e conforme as leis.

A partir daí, Rousseau desdobra dois argumentos. De uma parte, uma crítica virulenta e irônica às práticas usuais do anonimato, e principalmente do anonimato fingido, como aquele praticado por Voltaire. Para ele, esse é o alvo mais fácil, porque lhe permite denunciar o que pertence à hipocrisia mundana, signo de uma inautenticidade completa do discurso: "Vários têm mesmo o hábito de reconhecer seus livros para deles se vangloriarem e de os negarem para se ocultar; o mesmo homem será o autor ou não o será perante o mesmo homem, segundo eles estejam em uma audiência ou em uma ceia [...]. Dessa maneira, a segurança não custa nada para a vaidade". ${ }^{22}$ Mas a crítica essencial de Rousseau diz respeito ao fato de não the ter sido dada a possibilidade de se defender. Porque havia assinado e reivindicado seu texto, afirma ele, não era possível dissociá-lo de sua pessoa. Não é o próprio texto que é passível de condenação, e sim o ato de enunciação e a intenção do autor:

Quando um autor desajeitado, isto é, um autor que conhece seu dever, que quer cumprilo, acredita-se obrigado a nada dizer para o público sem reconhecê-lo, sem nomear-se, sem

\footnotetext{
${ }^{19}$ Ver KELLY, Christophe. Rousseau as Author. Consecrating One's Life to the Truth. Chicago: The University of Chicago Press, 2003.

${ }^{20}$ Lettre à Mgr. de Beaumont, em ROUSSEAU, Oeuvres complètes..., op. cit., p. 930. [Edição brasileira: ROUSSEAU, Jean-Jacques. Carta a Christophe de Beaumont e outros escritos sobre a religiáo e a moral. São Paulo: Estação Liberdade, 2005.]

${ }^{21}$ Sobre as questóes políticas e teóricas desse texto longamente subestimado pela crítica rousseauniana, ver BERNARDI, Bruno; GUÉNARD, Florent; SILVESTRINI, Gabriella (Dir.). Religion, liberté, justice. Sur les Lettres écrites de la montagne de J.-J. Rousseau. Paris: Vrin, 2005.

${ }^{22}$ ROUSSEAU, Jean-Jacques. Lettres écrites de la montagne. Oeuvres complètes. t. III. Paris: Gallimard, "Bibliothèque de la Pléiade”, 1964. p. 791-792. [Edição brasileira: ROUSSEAU, Jean-Jacques. Cartas escritas da montanha. São Paulo: Editora Unesp, 2006.]
} 
mostrar-se para responder pelo que diz, então a equidade — que não deve punir como um crime o equívoco de um homem honrado - exige que se proceda com ele de uma outra maneira. Ela quer que não se separe a causa do livro daquela do homem, visto declarar ele, ao colocar aí o seu nome, não desejar separá-las. Ela quer que não se julgue a obra, que não pode responder, senão após ter-se ouvido o autor, que responde por ela. ${ }^{23}$

Há aí uma teoria muito forte da responsabilidade penal do autor, da impossibilidade de distinguir o livro do autor: "neste ponto, a distinção entre o livro e o autor é inepta, visto não ser o livro passível de punição", ${ }^{24}$ afirma Rousseau.

É preciso ver que há algo extremamente potente e original nisso. Sabemos que, na arqueologia foucaultiana da função autor, a assinalação penal dos textos a um autor, que é um de seus estratos, é essencialmente uma operação do poder e exerce uma função repressiva. ${ }^{25}$ Ela é, pelo contrário, fortemente reivindicada por Rousseau, porque diz respeito em parte à parrhésia, isto é, o gesto de dizer a verdade, cuja força advém do fato de colocar em perigo a vida do autor, ao confrontá-lo diretamente com o risco da violência. $\mathrm{O}$ que está em jogo para Rousseau é o próprio ato de interpretação do texto. $\mathrm{O}$ sentido de um escrito depende da pessoa que o assinou, de suas intençôes, de sua moral. É o fato de o autor conformar-se aos seus princípios que dá a seus textos uma força persuasiva; o valor de verdade de um texto é indissociável da pessoa mesma do autor. O que, aliás, Rousseau resume com uma formulação contundente: "Se Sócrates tivesse morrido tranquilamente em seu leito, hoje talvez questionássemos se ele não passou de um sofista habilidoso". ${ }^{26}$ Donde a situação propriamente inaceitável colocada em cena por Rousseau, juge de Jean-Jacques: que existam dois Jean-Jacques, o autor dos livros e o autor dos crimes, é uma contradição absolutamente insustentável. Um homem mau não pode escrever textos que sirvam de inspiração moral. Um homem mau que escrevesse textos tão belos quanto aqueles de Jean-Jacques seria "um cadáver moral". ${ }^{27}$

Como se vê, a afirmação de uma responsabilidade jurídica e política de Rousseau tende para a reivindicação de um laço moral indissociável entre a obra e o autor, entre o discurso filosófico e a vida virtuosa. Ora, como o mostrou muito bem Foucault, a parrhésia, em sua versão socrática, mas ainda mais na tradiçáo cínica, implica um laço indissolúvel entre o discurso da verdade, o dizer-verdadeiro, e a escolha de um modo de vida conforme a esse discurso, que exiba a ruptura com os códigos habituais de uma sociedade corrompida. ${ }^{28}$ Trata-se de

\footnotetext{
${ }^{23}$ Ibid.

${ }^{24}$ Ibid.

${ }^{25}$ FOUCAULT, Michel. Qu'est-ce qu'un auteur? (1969). Dits et écrits. t. I. Paris: Gallimard, 1994.

${ }^{26}$ ROUSSEAU, Jean-Jacques. Discours sur cette question : quelle est la vertu la plus nécessaire aux héros?, 1751. Disponível em: <http://fr.wikisource.org/wiki/Collection_compl\%C3\%A8te_des_\%C5\%93uvres_ de_J._J._Rousseau/Tome_7/Texte_entier>.

${ }^{27}$ ROUSSEAU. Rousseau juge de Jean-Jacques, op. cit., p. 668.

${ }^{28}$ FOUCAULT, Michel. Le courage de la vérité: le gouvernement de soi et des autres II. Paris: Gallimard; Seuil, 2009. [Edição brasileira: FOUCAULT, Michel. A coragem da verdade. São Paulo: WMF Martins Fontes, 2011.]
} 
uma postura fortemente reivindicada por Rousseau desde seu rompimento ostensivo com as práticas mundanas da literatura. Donde, nele, esse ir e vir permanente entre seus princípios e sua vida. Donde essa busca permanente do escândalo, que lhe foi amiúde criticada, e que diz respeito justamente à busca de uma "forma de existência como escândalo vivo da verdade", na qual Foucault via o essencial da herança cínica. Não é, aliás, anódino o fato de Rousseau ter sido frequentemente comparado com Diógenes por seus inimigos.

Mas, em Rousseau, esse laço entre vida pessoal e preocupação de veridição é mais ambígua do que parece. Ela é indissociável de uma relação muito ambivalente com a preocupação de reconhecimento e com o julgamento dos outros, que, como mostrou Barbara Carnevali, está no cerne tanto de sua antropologia social quanto de sua obra autobiográfica. ${ }^{29} \mathrm{~A}$ estratégia do escândalo, frequentemente utilizada por Rousseau em sua ruptura ostensiva com os Grandes, com os hábitos mundanos ou com os códigos de publicação literária, não é somente um gesto de fundação ética articulado à coragem da verdade; ele é ameaçado na mesma medida pelo exibicionismo moral, e até mesmo por uma suspeita de estratégia publicitária. É aqui que Rousseau encontra as contradiçôes dessa encenação do nome próprio - e do regime de celebridade para o qual ela o conduz.

\section{Honra e celebridade: o reconhecimento do nome}

Para Rousseau, a reivindicaçáo do nome foi sempre também uma demanda de reconhecimento. No texto das Cartas escritas da montanha que acabamos de comentar, um dos elementos mais impressionantes é a onipresença do vocabulário da honra. Aquilo que Rousseau censura ao Pequeno Conselho é ter "assassinado sua honra", é tê-lo "mesmo aviltado pela máo do carrasco, em obras que trazem seu nome". ${ }^{30} \mathrm{O}$ texto todo é marcado pela oposiçáo entre o homem honrado, que faz questão de assinar os livros que publica (poder-se-ia dizer que se tratava para ele de uma questáo de honra) e a infâmia que o atinge pela condenaçáo do seu livro: "Quando queima um livro, o que faz o carrasco? Desonra ele as folhas do livro? Quem jamais ouviu dizer que um livro tivesse uma honra?"31 A utilização maciça do vocabulário da honra e da desonra, aqui, pode surpreender, a tal ponto ele parece fortemente conotado pelo ethos aristocrático. Para Rousseau, a associaçáo entre a honra e o nome diz respeito a uma nova representação do ato de escrita, e notadamente de uma escrita pensada como socialmente útil, como um modo de dignificar o papel do escritor. Mas, na verdade, a honra associada à escrita é mais ambígua do que parece, pois o sucesso literário é, por si só, um modo de honrar seu nome.

\footnotetext{
${ }^{29}$ CARNEVALI, Barbara. Romanticismo et riconoscimento. Figure della coscienza in Rousseau. Il Mulino: Ricerca, 2004.

${ }^{30}$ ROUSSEAU, Jean-Jacques. Lettres écrites de la montagne, op. cit., p. 791.

${ }^{31}$ Ibid.
} 
Assim, foi pelo desejo de igualar Jean-Baptiste Rousseau, "um homem célebre que possuía o mesmo nome que [ele]", que o jovem Rousseau redigiu seus primeiros ensaios poéticos, ${ }^{32}$ como reconheceu nas Confissóes. Mais tarde, em fragmentos autobiográficos, ele escreverá: "Alguns autores matam-se para fazer chamar o poeta Rousseau de o grande Rousseau, durante minha vida. Quando eu estiver morto, o Poeta Rousseau será um grande Poeta. Mas não será mais o grande Rousseau." ${ }^{33}$ Existem ainda outros testemunhos da importância atribuída por Rousseau, no início de sua carreira, ao seu nome e ao fato de se distinguir dos Rousseau já célebres. Em 1750, quando o prêmio da Academia de Dijon fez-lhe alcançar a celebridade e Raynal escreveu-lhe pedindo que lhe "abrisse sua pasta", Rousseau respondeu-lhe queixando-se de que o tomassem, equivocadamente, por um poeta, porque o confundiam com um homônimo (Pierre Rousseau de Toulouse, sem dúvida): "Uma coisa singular é que, tendo publicado outrora uma única obra em que certamente não era questão de Poesia, hoje façam-me Poeta, mau grado meu. Todo dia me vêm cumprimentar por Comédias e outras peças de versos que eu não fiz e não sou capaz de fazer. A conformidade do nome do autor com o meu é o que atrai para mim essa honra." ${ }^{4}$

Toda a ambiguidade da política do nome próprio por ele conduzida encontra-se nessa associação entre o sucesso literário, a utilidade social do discurso verdadeiro e a honra do nome. Pois essa identificação é totalmente reversível, a um ponto tal que a celebridade do nome será vivida por Rousseau, a partir dos anos 1760, como uma maldição. No plano da responsabilidade autoral, em primeiro lugar, ele não cessará de datar seus infortúnios de 1762 e, portanto, do início das perseguiçôes que o levaram a fugir da França, depois de Genebra, e que o obrigaram mesmo - e esse foi seu ápice - a recorrer a um nome falso para se esconder. Para além dos ataques jurídicos, contra os quais é sempre possível fazer frente e responder com novos textos que trazem seu nome, Rousseau persuade-se de que seus inimigos fazem circular com seu nome textos alterados, falsificados, e até mesmo livros que ele de modo algum escreveu e que eles publicam para enganar o público ao seu respeito. Embora tenha deixado de escrever, seus inimigos, afirma ele, "fazem-no incessantemente garatujar livros - e tomam grande cuidado de que esses livros, muito dignos das penas de onde saem, desonrem o nome que fazem com que carreguem". ${ }^{35}$ Aqui, já não importa apenas a questão da autoridade judiciária, mas também aquela, novamente, da honra e do renome. A desonra recai indissociavelmente sobre o nome de autor e sobre o indivíduo que o carrega.

Donde a necessidade de repudiar todos os textos que, doravante, trazem seu nome. Rousseau chega ao ponto de fazer circular, em 1774, uma carta manuscrita e assinada na

\footnotetext{
${ }^{32}$ Id., Les confessions. Oeuvres complètes, op. cit., t. I, p. 157. [Edição brasileira: ROUSSEAU, Jean-Jacques. Confissóes. São Paulo: Edipro, 2007.]

${ }^{33}$ Id. Mon portrait. Oeuvres complètes, op. cit., t. I, p. 1129.

${ }^{34}$ Carta de Rousseau ao abade Raynal, 25 de julho de 1750, Correspondance complète, op. cit., t. II, p. 132136, aqui p. 133.

${ }^{35}$ ROUSSEAU, Jean-Jacques. Rousseau juge de Jean-Jacques, op. cit., p. 913.
} 
qual repudia todos os futuros escritos assinados com seu nome. J.-J. Rousseau "declara todos os livros antigos ou novos, que se imprime ou se imprimirá doravante com o seu nome, e onde quer que seja, falsos ou alterados, mutilados e falsificados com a mais cruel malignidade, e repudia-os, a uns como já não sendo sua obra, e a outros como lhe tendo sido falsamente atribuídos". É a assinatura manuscrita que se torna o garantidor do nome, em lugar do nome na capa do livro, que, por sua vez, é colocado sob suspeita. Vemos aqui o paradoxo no qual se abisma Rousseau. ${ }^{36}$

Em segundo lugar, o sucesso de Rousseau e de suas obras e, por conseguinte, a celebridade de seu nome voltam-se contra ele. Para começar, ao suscitar os ciúmes dos outros autores e ao isolá-lo dentro do mundo literário — o que ele resumiu assim: "Tão logo tive um nome, deixei de ter amigos." ${ }^{37}$ Mas, sobretudo, ao falsificar as relaçóes com seu público, pois o nome é o vetor da celebridade experimentada por Rousseau: "O nome de Rousseau é célebre em toda a Europa”, escreve Jean-Baptiste de La Harpe ${ }^{38}$ Essa celebridade do nome, promovida notadamente pela imprensa, amplia consideravelmente o número de pessoas que conhecem o nome de Rousseau e associam-lhe um certo número de ideias, sem nunca tê-lo encontrado nem lido seus livros. Trata-se aqui de um regime de notoriedade bastante diferente dos mecanismos clássicos da reputação, que permanecem circunscritos a meios restritos de inter-reconhecimento. Ao contrário, o nome de Jean-Jacques Rousseau circula de maneira incontrolável e remete doravante menos ao indivíduo que ele é, ou quer ser, que à pessoa célebre que ele se tornou, esse personagem cujos feitos e gestos são narrados pelas gazetas, cujos livros provocam a polêmica e o escândalo. Pessoas que não o conhecem procuram conhecer as anedotas de sua vida privada e invocam-no em favor delas. Nesse ponto, o nome já não é o garantidor de uma individualização, mas, pelo contrário, um obstáculo. Ele interpóe-se em sua relação com os outros. "Entre meus contemporâneos, escrevia ele já em 1764 em um esboço de preâmbulo para as Confissóes, há poucos homens cujo nome seja mais conhecido na Europa e cujo indivíduo seja mais ignorado [...]. Cada um me figurava segundo suas fantasias sem temer que o original viesse desmenti-lo. Havia um Rousseau na alta roda e um outro, em retiro, que náo se lhe assemelhava em nada." ${ }^{39}$

Tocamos aqui na crítica mais geral feita por Rousseau quanto aos efeitos da celebridade, da manipulação das opiniôes e da credulidade do público. ${ }^{40} \mathrm{O}$ nome próprio — ao mesmo tempo nome de autor, identidade social e vetor de individualização — é evidentemente um potente revelador dos efeitos brutais da "funesta celebridade", na qual o reconhecimento

\footnotetext{
${ }^{36}$ BENNINGTON, Geoffrey. Dudding. Des noms de Rousseau. Paris: Galillée, 1991.

${ }^{37}$ ROUSSEAU, Les confessions, op. cit., p. 362.

${ }^{38}$ Do mesmo modo, Mercier escreve em seu Tableau de Paris (Paris, Mercure de France, 1998 [1783], t. I, p. 45): "os três homens do meu tempo que mais chamaram a atenção dos parisienses faladores foram o rei da Prússia, Voltaire e Jean-Jacques Rousseau”.

${ }^{39}$ ROUSSEAU, Jean-Jacques. Oeuvres complètes, op. cit., t. I, p. 1151.

${ }^{40}$ Sobre essa questão, permito-me remeter a LILTI, Antoine, “The Writing of Paranoïa: Jean-Jacques Rousseau and the Paradoxes of Celebrity", op. cit.
} 
cognitivo é totalmente desconectado do reconhecimento social: o identificamos, mas não o conhecemos. Podemos relembrar aqui o episódio, narrado na sexta caminhada, do pequeno mendigo que se coloca todo dia em seu caminho e o chama de "Senhor Rousseau", o que Rousseau comenta da seguinte maneira: ele o chamava assim "para mostrar que ele me conhecia bem, o que me ensinava, muito pelo contrário, que ele não me conhecia muito mais do que aqueles que o haviam instruído". Com efeito, conforme se assinalou, "Senhor" é sempre conotado negativamente em Rousseau. Chamá-lo de "Senhor Rousseau" é mostrar que se conhece seu nome, mas não seu caráter.

A promoção do nome em Rousseau corresponde a uma concepção do autor radicalmente diferente daquele de muitos de seus contemporâneos, mas possuidora de uma forte coerência. Rousseau reivindica uma completa responsabilidade política e moral de seus escritos, e constrói assim uma posição de singularidade levada ao limite - e que ele termina por experimentar segundo o modo da alienação. Esse paradoxo do nome célebre, em que o mais singular vetor de identidade pessoal, uma vez mediado por um público, torna-se o signo de um doloroso desapossamento, manifesta-se no famoso episódio narrado por Rousseau na segunda caminhada, quando ele é derrubado por um cachorro que tentara evitar uma carroça. Ele perde a consciência e acorda com o rosto ensanguentado, tendo esquecido até seu próprio nome. Não podemos deixar de nos impressionar, ao reler essa passagem, com o fato de que esse breve momento amnésico é descrito por Rousseau como um "momento delicioso", um verdadeiro reconhecimento: "eu nascia para a vida", "inteiramente entregue ao momento presente, eu náo me lembrava de nada". "Eu sentia em todo meu ser uma calma encantadora à qual, a cada vez que dela me lembro, não encontro nada de comparável em todo o conjunto de diversôes conhecidas". ${ }^{41}$ Ora, esse momento de felicidade, de presença pura no mundo corresponde justamente ao momento de esquecimento do nome. Todavia, esse nome vai ser-lhe muito rapidamente lembrado, por intermédio dos mecanismos da celebridade: a visita do tenente de polícia, que vem informar-se de sua saúde, mas inquieta Rousseau; e o anúncio de sua morte nos jornais, que lhe vale o duvidoso privilégio de ler, em vida, seu próprio necrológio.

\section{Referências bibliográficas}

BACZKO, Bronislaw. Job, mon ami: Promesse du bonheur et fatalité du mal. Paris: Gallimard, 1997.

BÉNICHOU, Paul. Le sacre de l'écrivain: Essai sur la naissance d'un pouvoir laïque dans la France moderne. Paris: Gallimard, 1973.

\footnotetext{
${ }^{41}$ ROUSSEAU, Jean-Jacques. Rêveries du promeneur solitaire. Oeuvres complètes, op. cit., t. I, p. 1005. [Edição brasileira: ROUSSEAU, Jean-Jacques. Devaneios do caminhante solitário. Porto Alegre: L\&PM Editores, 2008.]
} 
BENREKASSA, Georges. L'interlocuteur voltairien: le masque et la plume. In: MERVAUD, Christiane; MENANT, Sylvain (Dir.). Le Siècle de Voltaire, hommage à René Pomeau. v. 1. Oxford: The Voltaire Foundation, 1987.

BERNARDI, Bruno; GUÉNARD, Florent; SILVESTRINI, Gabriella (Dir.). Religion, liberté, justice. Sur les Lettres écrites de la montagne de J.-J. Rousseau. Paris: Vrin, 2005.

BIRN, Raymond. Fashioning and Icon: Jean-Jacques Rousseau and the Mémoires secrets. In: FORT, Bernadette Fort; POPKIN, Jeremy (Ed.). The Mémoires secrets and the Culture of Publicity in Eighteenth-Century France. Oxford: The Voltaire Foundation, 1998.

BONNET, Jean-Claude. Naissance du Panthéon : Essai sur le culte des grands hommes. Paris: Fayard, 1998.

CARNEVALI, Barbara. Romanticismo et riconoscimento. Figure della coscienza in Rousseau. Il Mulino: Ricerca, 2004.

DIAZ, José-Luis. L'Écrivain imaginaire: Scénographies auctoriales à l'époque romantique. Paris: Champion, 2007.

FERRET, Olivier. Vade mecum, vade retro. Le recours au pseudonyme dans la démarche pamphlétaire voltairienne. La Lettre Clandestine, n. 8, p. 65-82, 1999.

FOUCAULT, Michel. Le courage de la vérité: le gouvernement de soi et des autres II. Paris: Gallimard; Seuil, 2009. [Edição brasileira: FOUCAULT, Michel. A coragem da verdade. São Paulo: WMF Martins Fontes, 2011.]

. Qu'est-ce qu'un auteur? (1969). Dits et écrits. t. I. Paris: Gallimard, 1994.

GARETTA, Anne. Rousseau, juge de Jean-Jacques: Individu, identité et référence du nom propre". In: BROUARD-ARENDS, Isabelle (Dir.). Lectures de Rousseau : Les Dialogues. Rennes: Presses Universitaires de Rennes, 2003.

HEINICH, Natalie. L'Élite artiste : Excellence et singularité en régime démocratique. Paris: Gallimard, 2005.

KELLY, Christophe. Rousseau as Author. Consecrating One's Life to the Truth. Chicago: The University of Chicago Press, 2003.

LECLERC, Gérard. Le Sceau de l'oeuvre. Paris: Éditions du Seuil, 1998.

LILTI, Antoine, The Writing of Paranoïa: Jean-Jacques Rousseau and the Paradoxes of Celebrity. Representations, n. 103, p. 53-80, Summer 2008.

MORI, Gianluca. Anonymat et stratégies de communication : le cas de Pierre Bayle. La Lettre Clandestine, n. 8, p. 19-34, 1999.

MOSTEFAI, Ourida. Le Citoyen de Génève et la République des Lettres, étude de la controverse autour de la Lettre à D’Alembert de Jean-Jacques Rousseau. Nova York; Berlim; Oxford: Peter Lang, 2003. 
ROUSSEAU, Jean-Jacques. Correspondance complète. Ralph-Alexander Leigh (Ed.). t. V. Oxford: The Voltaire Foundation, 1962-1998.

. Discours sur cette question : quelle est la vertu la plus nécessaire aux héros?, 1751. Disponível em: <http://fr.wikisource.org/wiki/Collection_compl\%C3\%A8te_ des_\%C5\%93uvres_de_J._J._Rousseau/Tome_7/Texte_entier>.

- Julie ou la Nouvelle Héloïse. Ediçâo de René Pomeau. Paris: Garnier, 1960. p. 3. [Edição brasileira: ROUSSEAU, Jean-Jacques. Júlia ou A nova Heloísa. Campinas, SP: Editora da Unicamp; São Paulo: Hucitec, 2006.]

. Les confessions. Oeuvres completes. t. I. Paris: Gallimard, 1959. p. 157. [Edição brasileira: ROUSSEAU, Jean-Jacques. Confissóes. São Paulo: Edipro, 2007.]

. Lettre à Mgr. de Beaumont, em ROUSSEAU, Oeuvres completes. Paris: Gallimard, 1959. p. 930. [Edição brasileira: ROUSSEAU, Jean-Jacques. Carta a Christophe de Beaumont e outros escritos sobre a religião e a moral. São Paulo: Estação Liberdade, 2005.]

. Lettres écrites de la montagne. Oeuvres complètes. t. III. Paris: Gallimard, "Bibliothèque de la Pléiade", 1964. p. 791-792. [Ediçâo brasileira: ROUSSEAU, Jean-Jacques. Cartas escritas da montanha. São Paulo: Editora Unesp, 2006.]

. Mon portrait. Oeuvres completes. t. I. Paris: Gallimard, 1959. p. 1129.

. Rêveries du promeneur solitaire. Oeuvres completes. t. I. Paris: Gallimard, 1959. p. 1005. [Edição brasileira: ROUSSEAU, Jean-Jacques. Devaneios do caminhante solitário. Porto Alegre: L\&PM Editores, 2008.]

1959.

. Rousseau juge de Jean-Jacques. Dialogues. Oeuvres complètes. t. I. Paris: Gallimard,

SANDRIER, Alain. Le style philosophique du baron d'Holbach. Paris: Champion, 2004.

TURNOWSKI, Geoffrey. The Enlightenment Literary Market: Rousseau, Authorship and the Book Trade. Eighteenth Century Studies, v. 3, n. 36, p. 387-410, 2003. 